\title{
Smulkiojo verslo plètros „žaliosios“ energetikos sektoriuje galimybių vertinimas
}

\author{
Aušra Pažèraitè, \\ Mindaugas Krakauskas \\ Lietuvos energetikos institutas, \\ Breslaujos g. 3, LT-44403 Kaunas \\ El.paštas:ausra@mail.lei.lt; \\ mindaugas.krakauskas@gmail.com
}

\begin{abstract}
Straipsnyje analizuojamos smulkiojo verslo plètros galimybès energetikos sektoriuje. Ivvardijamos pagrindinès plètros prielaidos - politinès, ekonominès, socialinès ir techninès. Prielaidos analizuojamos remiantis pagrindiniais atsinaujinančių išteklių energijos sektorių reglamentuojančiais teisès aktais kartu su smulkiajam ir vidutiniam verslui skirtu įstatymu bei praktine ịstatymų taikymo patirtimi. Pateikiami kiekvienos prielaidos svarbiausi aspektai bei jų vertinimas.
\end{abstract}

Raktažodžiai: smulkusis verslas, „žalioji“ energetika, atsinaujinantys energijos ištekliai

\section{IVADAS}

Smulkusis verslas yra pripažįstamas kaip vienas pagrindinių demokratijos ir gyvybingos ekonomikos veiksnių. Šis verslas dèl savo specifikos yra paplitęs ịvairių paslaugų ir ypač prekybos srityje, kurioje smulkusis verslas sudaro net apie $97 \%$. Galima atrasti ir tokių ekonominès veiklos sričių, kur smulkiojo verslo įmonės sudaro ir $100 \%$.

Yra sričiu, kurios tradiciškai buvo vertinamos kaip didesniu imoniu veiklos erdvès. Pvz., elektros energijos ar šilumos gamyba. Deja, bet smulkiojo verslo dalies energetikos sektoriuje statistika nepateikiama. Atlikus statistinę analizę bei remiantis LR Smulkiojo ir vidutinio verslo plètros įstatyme pateikiamais apibrèžimais [1], kokios įmonès laikytinos smulkiosiomis ir vidutinemis, galima teigti, kad elektros energetikos sektoriuje smulkusis ir vidutinis verslas tesudaro apie $1 \% .2010$ m. Vokietijoje saulès ir vejo elektros energija sudarė apie 17 \% visos elektros energijos. Pusè vèjo ir trys ketvirtadaliai saulès elektros energijos yra pagaminama vietos, t. y. smulkiojo ir vidutinio verslo [2].

Krizės ir ekonominio nuosmukio laikotarpiu ypač svarbu skatinti žmonių verslumą, kaip galimybę patiems susikurti darbo vietas, neišvengiamai reikia ieškoti naujų sričių, kur smulkiojo verslo potencialas galètų būti naudingai panaudojamas visos valstybès mastu. Dar labai svarbu - smulkiojo, ypač inovatyvaus, verslo skatinimas, tai gali būti vienas iš būdų emigracijai stabdyti.

Toks požiūris svarbus ne tik Lietuvai, bet ir visai Europos Sąungai (toliau - ES). Kaip atsaką minètoms problemoms, ES valstybès narès nutare priimti naują strategiją „Europa 2020“ [3]. Pagrindiniai šios strategijos tikslai - žmonių užimtumo didinimas, mokslo tyrimų ir eksperimentinès plètros skatinimas, darnaus vystymosi užtikrinimas bei socialinès atskirties ir skurdo mažinimas.

Straipsnyje autoriai nagrinėja energetikos smulkiojo verslo plètros galimybes. Viena tokio pasirinkimo priežasčiu ta, kad tradicinè energetika buvo sukoncentruota stambiose monopolijose ir nepalikdavo vietos smulkiajam verslui [4]. Tačiau dèl dabar vykstančios pasaulinès „žaliosios“ energijos plètros beveik $60 \%$ visų naujai statomų elektrinių sudaro „žalioji“ elektros energijos gamyba [5] - visoje energetikos pramoneje neišvengiamai turi vykti ir vyksta didžiulès permainos. Dèl pastarųjų tendencijų atsiranda vis daugiau erdvės smulkiajam verslui. Kita vertus, taip pat 
pastebimas ir padidejjęs stambiųjų monopolijų dèmesys šiam sektoriui.

Tad būtina ịvertinti prielaidas, kurios yra susiformavę ir daro poveikị smulkiojo verslo plètrai Lietuvos „žaliosios“ energetikos sektoriuje. Bendruoju atveju plètros prielaidas galima suskirstyti i politinès, ekonominès, socialinès ir techninès kilmès.

\section{SMULKIOJO VERSLO PLĖTROS „ŽALIOSIOS“ ENERGETIKOS SEKTORIUJE PRIELAIDU VERTINIMO METODOLOGIJA}

Prielaidos išskirtos remiantis teorijos, gerosios praktikos pavyzdžių analizėmis bei empiriniais tyrimais. Prielaidų analizè ir vertinimas atlikti pasitelkiant ekspertinį vertinimą ir PEST (politinių, ekonominių, socialinių ir techninių veiksnių) analizę.

Ekspertiniai vertinimai yra taikomi ịvairių ūkio šakų tyrimuose. Ekspertiniams vertinimams reikalingos specialios ekspertinès žinios ir patyrimas, kurị turi tik nedaugelis specialistų. Energetikos sektoriaus smulkiųu ir vidutinių imonių patyrimas yra ypač vertingas, tačiau jị turi tik nedaugelis ịmonių. Todèl smulkiojo ir vidutinio verslo plètros veiksnių tyrimui ypač taikytinas ekspertinių vertinimų metodas. Tyrimui atlikti pasirinktas ekspertinis individualiojo vertinimo metodas - anketinė apklausa.

Nustatant tinkamą ir pakankamą ekspertų skaičuu vadovaujamasi metodologinėmis prielaidomis, suformuluotomis klasikinëje testų teorijoje, kuri teigia, jog agreguotų sprendimų patikimumą ir priimančiųjų sprendimą (šiuo atveju - ekspertų) skaičių sieja greitai gęstantis netiesinis ryšys. İrodyta, jog agreguotų ekspertinių vertinimų moduliuose su vienodais svoriais nedidelès ekspertų grupés sprendimų ir vertinimų tikslumas nenusileidžia didelès ekspertų grupès atliktų sprendimų ir vertinimų tikslumui (1 pav.) [6].

Atliktame tyrime taikytas ekspertinis vertinimas. Ekspertams buvo pateiktas atviras klausimas - kokie veiksniai daro ịtaką smulkiojo ir vidutinio verslo plètrai „žaliosios“ energetikos sektoriuje? Taip pat ekspertų paprašyta ịvertinti, kokia kiekvieno veiksnio ịtaka: teigiama ar neigiama.

Ekspertai buvo parenkami tiek pirmajam, tiek antrajam etapui. Atrankos kriterijai:

1) užimamos pareigos;

2) universitetinis išsilavinimas;

3) darbo patirtis energetikos srityje (ne mažiau kaip 3 metai).

Tyrime dalyvavo penki ekspertai: trys energetikos srityje dirbantys mokslininkai bei du energetikos srities smulkiụjų ir vidutinių įmonių atstovai.

Ekspertų nurodytiems veiksniams struktūrizuoti buvo pasirinkta PEST analizè. Tirti politiniai, ekonominiai, socialiniai ir techniniai veiksniai, t. y. bet kokio reiškinio ar objekto išorine aplinka [7]. Viena vertus, tokiu veiksniu galima išskirti daugybę ir kiekvieną ivertinti tikrai sunku. Todèl PEST analizè dažnai derinama su ekspertiniu vertinimu, kad ịvardinus net daugeli veiksnių (remiantis ekspertiniu vertinimu) būtu galima išrinkti tik pakankamai svarbius, ittakingus ir vèliau vertinti bei nagrinèti tik pasirinktuosius.

Kita vertus, pastaroji analizė ypač gerai tinka, kuomet reikia išskirti, struktūrizuoti ir ivertinti būtent naujai susiformavusio reiškinio, proceso, naujai i rinką ivedamos prekès ir t. t. išorinę aplinką. Išorinè aplinka daro dideli ir dažnai sunkiai kontroliuojamą poveiki bet kurio iš minètu aspektų vyksmui. Pastaroji ịtaka gali būti tiek teigiama, tiek ir neigiama.

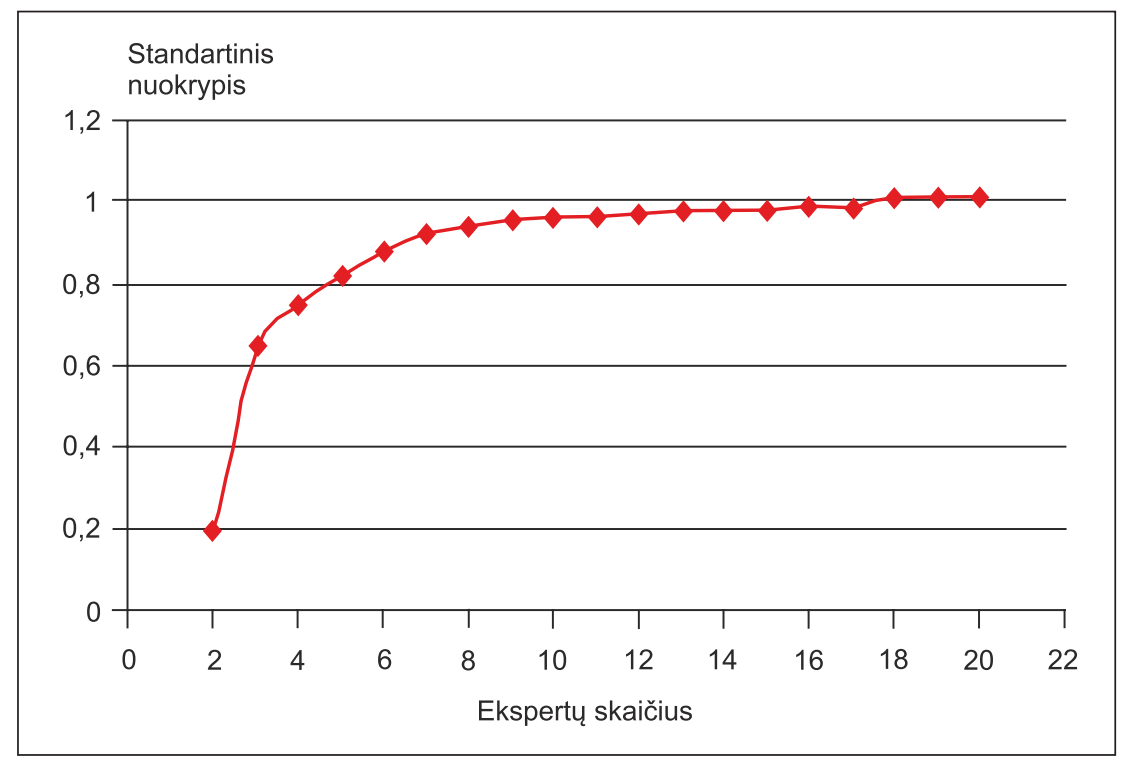

1 pav. Ekspertų vertinimų standartinio nuokrypio priklausomybė nuo ekspertų skaičiaus; šaltinis [6] 


\section{SMULKIOJO VERSLO PLĖTROS „ŽALIOSIOS“ ENERGETIKOS SEKTORIUJE PRIELAIDŲ VERTINIMO REZULTATAI}

Remiantis PEST analizès metu aptariamų veiksnių eiliškumu, toliau pateikiama ir apibūdinama smulkiojo verslo plètros „žaliosios“ energetikos sektoriuje išorinè aplinka.

\section{Politiniai veiksniai}

Pirmiausia būtina pabrèžti, kad bet kokios rūšies prielaidos smulkiajam verslui „žaliosios“ energetikos sektoriuje gali būti išnaudotos tik tuomet, jei kelio neapsunkins teisiniai bei administravimo ypatumai, kuriuos lemia tuo metu vykdoma valstybės politika. Kaip jau minèta anksčiau, pagrindiniai sektoriaus reglamentavimo principai, nuostatos ir būdai suformuluoti LR Atsinaujinančių išteklių energetikos įstatyme (AIE). Šis įstatymas sektoriui suteikia daugiau aiškumo ir nuoseklumo, tačiau svarbu, kad yra likę spręstinų dar senų problemų, taip pat atsirado ir naujų, pvz., aukciono principo taikymas (straipsnyje bus išsamiau aptartas).

Sèkmingai taikyti ịstatymą trukdo tai, kad net ne visi istatymą lydintieji dokumentai yra patvirtinti. Tačiau šis istatymas smulkiajam verslui aktualus ir patrauklus, nes jame yra reglamentuojamas supaprastintas administravimas, priklausomai nuo atsinaujinančius energijjos išteklius (AEI) naudojančių elektrinių ịrengtos galios. Atitinkamai ịstatyme išskiriami mikro- ir maži projektai, kuriu elektriniu galingumas negali viršyti $30 \mathrm{~kW}$ ir $350 \mathrm{~kW}$. Paminètina, kad objektų suskirstymas pagal gamybos įrenginių galią (su nedidele išimtimi, kai naudojami šilumos siurbliai) numatomas tik gaminant elektros energiją, prijungimo išlaidų kompensavimas šilumos ir energijos oro aušinimo gamybai iš AEI pajègumų visai netaikomas, o prijungiant bioduju gamybos įrenginius taikomas tik vienos rūšies, t. y. dujų sistemų operatorius gamintojui kompensuoja $40 \%$ prijungimo kainos [8]. Taigi, nuoseklios pozicijos trūkumas gali sąlygoti skirtingą AEI technologijų plètrą, kuri priklauso nuo pagaminamos energijos paskirties.

AIE įstatyme teigiama, kad „Atsižvelgiant į nedidelès įrengtosios galios elektrinių (iki $350 \mathrm{~kW}$ ), naudojančių atsinaujinančius energijos išteklius, ribotą dydị ir galimą poveikị ir siekiant išvengti neproporcingos finansinès bei administracinès naštos, atsakingos institucijos užtikrina, kad nedidelès įrengtosios galios elektrinių projektavimui ir statybai, išskyrus patvankinio tipo hidroelektrines, būtų taikomi supaprastinti reikalavimai, nereikalaujant rengti detaliųjų planų ir keisti pagrindinę žemès naudojimo paskirti, jei tai neprieštarauja vietos tvarkymo ir naudojimo reglamentams.“ Taip pat 5 îstatymo punkte teigiama, kad „Kaimo vietovèse statant pavienes ne didesnès kaip $350 \mathrm{~kW}$ ịrengtosios galios vèjo elektrines ir (ar) saulès šviesos energijos elektrines, nereikalaujama keisti žemès naudojimo paskirties, rengti detaliųjų planų ir keisti bendrojo plano sprendinių, jei tai neprieštarauja vietos tvarkymo ir naudojimo reglamentams." Tačiau supaprastintų sąlygų kol kas nèra. Kaip jau minèta, vietoje detaliųjų planų atsiranda specialieji planai, tik nèra taisyklių, kaip jais naudotis. Vietoje buvusių barjerų ir sunkumų kuriami nauji.

Apibendrinant galima teigti, kad aiškiau apibrěžti yra tie reikalavimai ir skatinimo būdai, kurie taikomi mažesnèms kaip $30 \mathrm{~kW}$ irengtosios galios elektrinèms. Nors ir čia yra praktiniu iggyvendinimo problemų, kai techninèse prijungimo sąlygose vis dar nurodomi pertekliniai reikalavimai prisijungiančiajam savo lěšomis atlikti tam tikrus prisijungimo prie tinklų darbus.

\section{Ekonominiai veiksniai}

Viena iš varomujų jègų ịmonių plètrai energetikos srityje yra masto ekonomijos désnis, veikiantis per gamybos veiklos efektyvumo didinimą. Kaip matyti 2 pav., kuris parengtas pagal Lietuvoje viešai prieinamus duomenis, nuostata, kad kuo vèjo elektrinè yra didesnès instaliuotos galios, tuo jos efektyvumas yra didesnis, pasitvirtina.

Tačiau „žaliojoje“ energetikoje ekonomikos dydžio dèsnis ne visada galioja. Ypač tai akivaizdu analizuojant saulès šviesos elektriniu duomenis. Lietuvoje, kaip ir kitur, lyginamosios investicijos i $10 \mathrm{~kW}$ galios saulès šviesos elektrinę yra panašios kaip ir $1 \mathrm{MW}$ galios, o efektyvumas, nepriklausomai nuo saulès šviesos elektrinès instaliuotos galios kiekio, išlieka panašus.

Nors 3 pav. ir galima pamatyti efektyvumo skirtumų, tačiau jie pasitaiko nepriklausomai nuo elektrinès dydžio. Taip yra todèl, kad efektyvumas, jei saulètumas yra panašus, labiausiai priklauso nuo pasirinktos technologijos, bet ne nuo instaliuotos galios dydžio. Pirmosios saulès šviesos elektrinès efektyvumą vertinti gana sunku, nes pateikiami duomenys apie pastarąją elektrinę neatitinka realybės, t. y. praktiškai elektros energiją gaminanti galia yra gerokai didesnè nei deklaruojama, o pagamintos elektros energijos kiekis yra pateikiamas tikslus, atsiranda netikslumų.

Tarp kitu ekonominių veiksnių svarbu ir energetikos sektoriuje sukuriama vertẻ visuomenei. Amerikiečių tyrimai rodo, kad vienas doleris vietinių verslininkų investuotas i vèjo energetikos verslą vietinei bendruomenei duoda tris kartus daugiau naudos nei stambus išorès investuotojas.

Dar dažnai pasaulyje „žaliosios“ energetikos verslas yra remiamas dèl nepakankamai vertinamų išorinių kaštų ir kad jis yra jaunas, nepasiekęs tokios brandos, kad galètu konkuruoti su senuoju monopolizuotu tradicinès energetikos verslu. Tačiau „žaliosios“ energetikos vartojimo neišvengsim, nes daugeliu ES dokumentų yra suformuota misija pakeisti iškastinį kurą naudojančią energetiką „žaliąja“. 


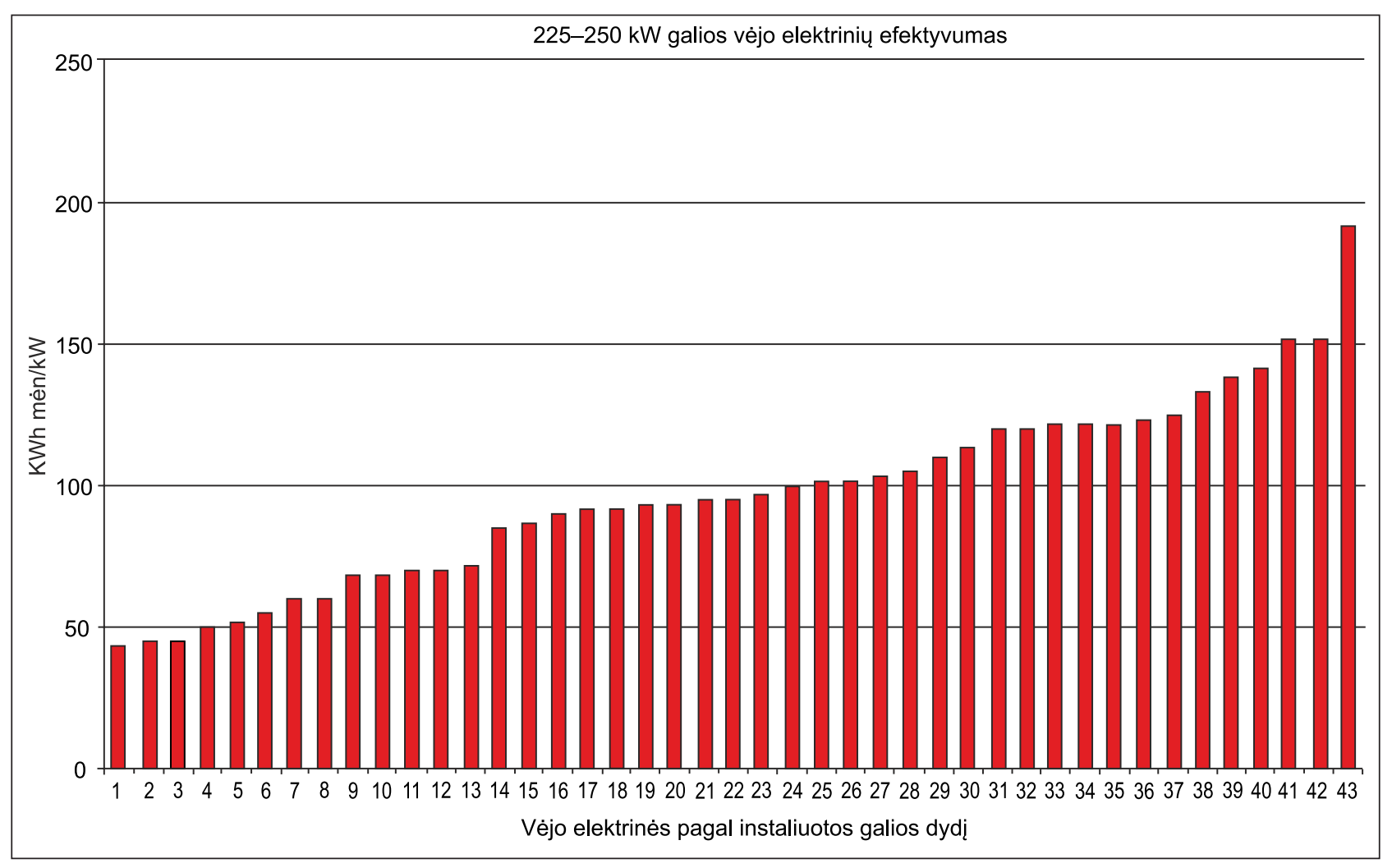

2 pav. Vèjo elektrinių efektyvumas, priklausantis nuo instaliuotos galios dydžio

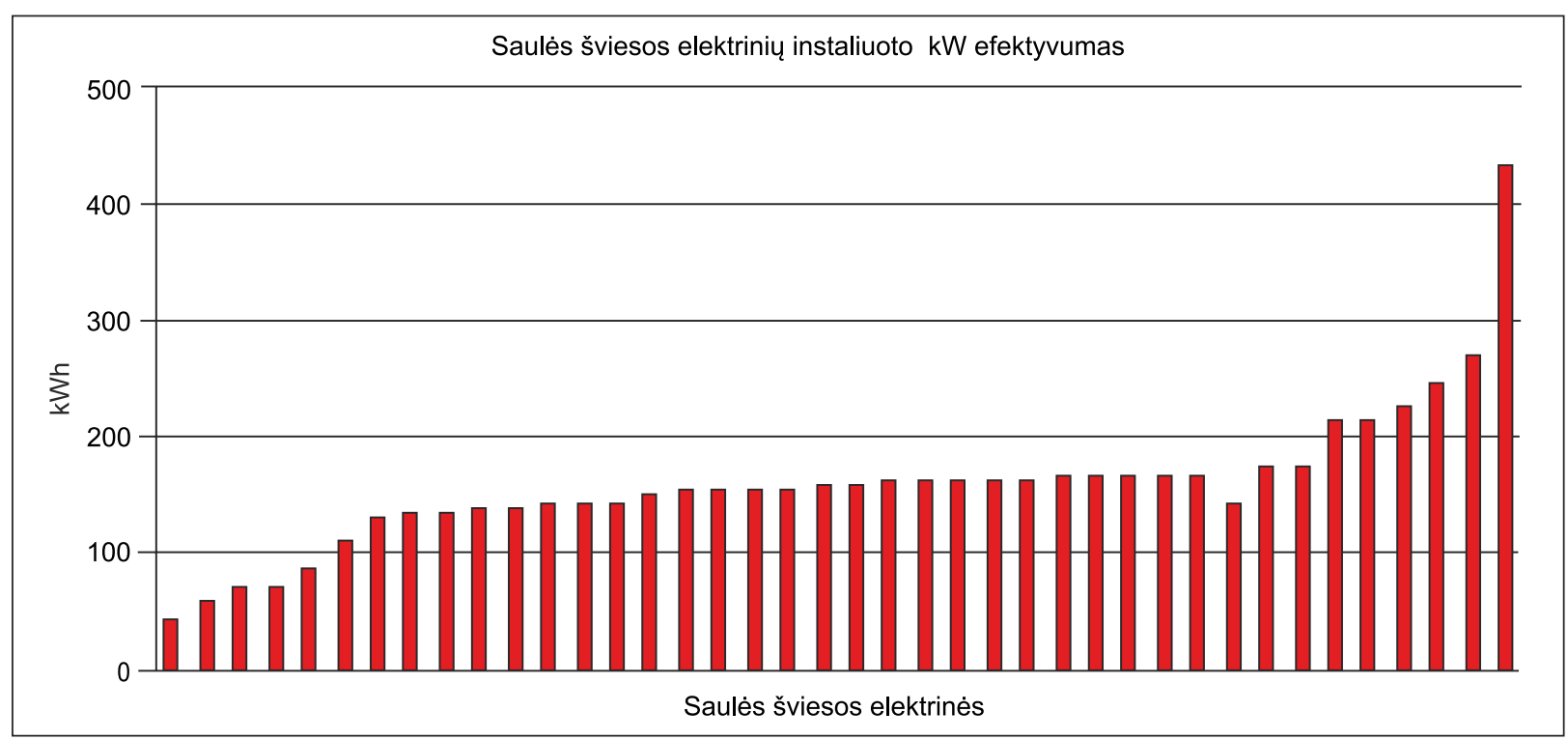

3 pav. Sauless šviesos elektrinių efektyvumas, priklausantis nuo instaliuotos galios dydžio

Be to, siekiant ekonomikos tobulumo skatinant verslumą ir darbo vietų kūrimą bei siekiant kitokios naudos visuomenei (nepriklausomai nuo jo veiklos rūšies) smulkusis verslas irgi yra remiamas. Todèl nenuostabu, kad pasaulyje vis dažniau prabylama būtent apie smulkiosios „žaliosios“ energetikos plètrą.

AIE įstatyme yra numatoma AEI panaudojimo energetikoje skatinimo tvarka. Tai būtų vertintina kaip teigiamas tiek „žaliosios“ energetikos, tiek smulkiojo verslo skatinimas, jei tokia tvarka būtų patvirtinta. Plačiau paanalizavus AIE bei Smulkiojo ir vidutinio verslo plètros įstatymuose remimą ir skatinimą, galima teigti, kad tos nuostatos tarpusavyje nesuderintos.

Šiandieninis elektrinių skirstymas pagal energetinę galią nesutampa su LR Smulkiojo ir vidutinio verslo plètros isstatymu, t. y. AIE j̧statyme daugiausia realių palengvinimų 
ir paskatinimų yra skirta namų ūkiams ir ypač smulkiesiems gamybiniams dariniams. Pastarųjų savininkams nereikia dalyvauti aukcione, taip pat nereikia igyvendinti nuostatų, kurios taikomos elektrinėms, kurių îrengtoji galia yra didesnè kaip $30 \mathrm{~kW}$.

Smulkiojo ir vidutinio verslo plètros ịstatyme numatoma, kad taikant skatinimo priemones prioritetas turi būti teikiamas ne tik labai mažoms įmonems, bet ir mažoms imonèms [1]. AIE įstatyme išskiriamoms elektrinèms, kurių ịrengtoji galia yra ne didesnè kaip $350 \mathrm{~kW}$, numatomas skatinimas yra tik minimalus, nes panaikinus reikalavimą keičiant detaliuosius planus, derinimas su teritoriju plètros planais pakeičiamas atitikimu specialiesiems planams [8].

Be to, iejeimui į rinką taikant ịstatyme numatytą aukciono principą, pageidaujantys tapti gamintojais tam tikroje teritorijoje turi laimèti konkursą, pasiūlydami mažiausią fiksuotą tarifą. Tada gimsta ipareigojimas labai mažoms ir mažoms įmonèms kaina konkuruoti dèl gamybos kvotu su stambiaisiais gamintojais. Apskritai aukciono principas norint prijungti naują AIE jègainę atsižvelgiant ị pasaulinę praktiką vertinamas kaip neefektyvus, nes konkuruojant dèl kvotos, pasiūlant mažiausią fiksuotą tarifą, pastarieji susiejami su kintamomis rinkos kainomis, taigi negarantuoja investuotojams stabilumo ir patikimumo, o aukcionai neskatina naudoti naujų technologijų. AIE įstatymas galioja, tačiau kol kas neįvyko nė vienas aukcionas, nors norinčiųjų dalyvauti tikrai yra. Be to, pati aukciono vykdymo tvarka nèra korektiškai išbaigta ir nuosekli.

Teigiamai galima įvardinti AIE įstatymo nuostatą (21 straipsnis, 3 punktas), kad elektrinès iki $30 \mathrm{~kW}$ prijungimo darbai atliekami nemokamai, o iki $350 \mathrm{~kW}$ galios elektrinès savininkas moka $60 \%$ jos prijungimo išlaidų.

Be to, remiantis AIE įstatymo 19 str. 3 punktu, mikroir mažiems projektams nenumatoma prievolè ịrengti nuotolinio valdymo priemonių. Ši nuostata suteikia galimybę mažesniems nei $350 \mathrm{~kW}$ gamintojams sumažinti reikiamas investicijas.

Apibendrinant galima teigti, kad ekonominis skatinimas realiai numatomas tik ypač mažoms (iki $30 \mathrm{~kW}$ ) elektrinèms, nes pastarųjų savininkams nereikia dalyvauti aukcione - ju pagamintos elektros energijos kainos yra fiksuotos ir nustatomos Valstybinès kainų ir energetikos kontrolès komisijos (toliau - VKEKK). Šị teiginị iliustruoja 4 pav., kuriame matosi labai ryškus saulès šviesos elektrinių instaliuotosios galios padidèjimas (pradedant $2011 \mathrm{~m}$. pabaiga). Reikia atkreipti demesi, kad pastarasis augimas atsirado būtent dèl smulkiujų elektrinių plètros.

Vèjo jẻgainių plètros tendencijos yra kitokios (5 pav.). Viena vertus, efektyvesnès yra didesnès elektrinès. Kita vertus, kaip jau minèta anksčiau, jų plètrai didesnio ekonominio skatinimo nèra.

Didesnè elektriniu plètra akivaizdi 2011 m., tai lèmè siekis spèti pradèti veiklą iki įsigalios aukciono taisyklès.

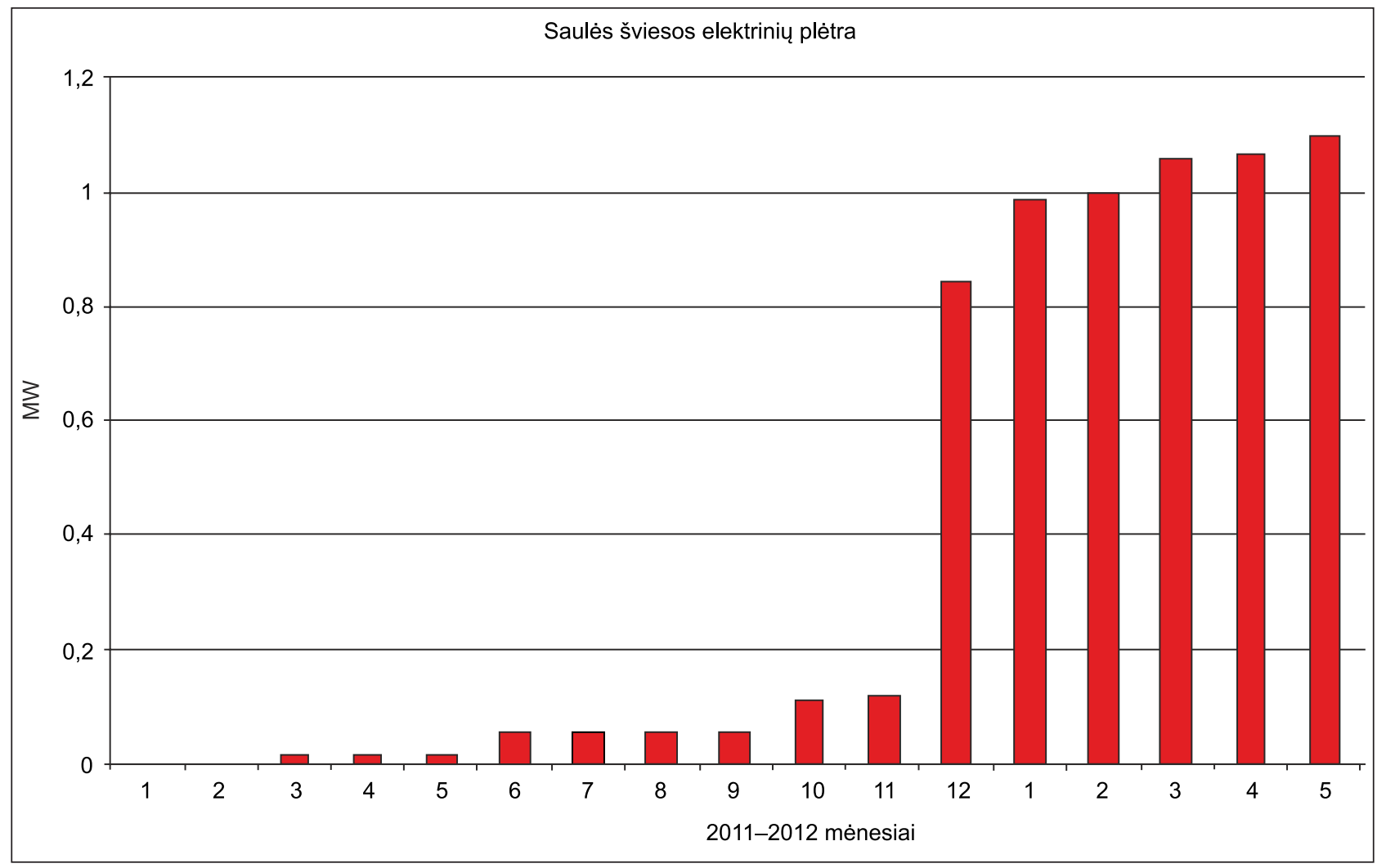

4 pav. Saulès šviesos elektrinių plètra Lietuvoje 


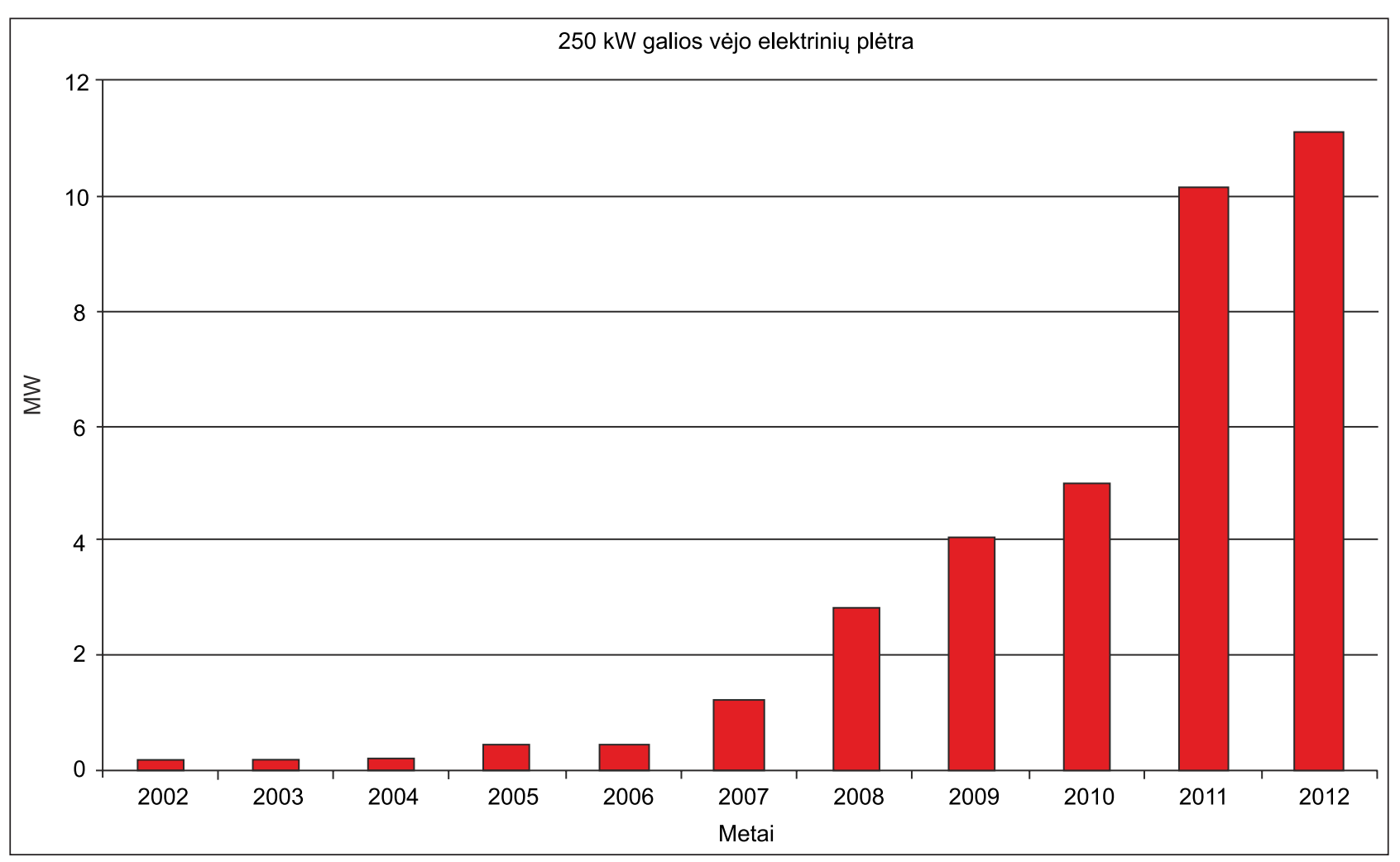

5 pav. Vejjo elektrinių plètra Lietuvoje

\section{Socialiniai veiksniai}

Pastaruoju metu jau yra mokslinių ir praktinių publikacijų apie socialinị požiūrị i $\mathfrak{l}$,žaliosios“ energetikos pramonę, kur matomas didejjantis gyventoju pasipriešinimas stambaus kapitalo imonèms, siekiančioms naudoti atsinaujinančius energijos išteklius, esančius artimoje gyventojų aplinkoje.

Dèl energetiniais bei finansiniais ištekliais pagrịstu lobistinių gebėjimų, daugelyje pasaulio šalių vyravo administracinè praktika, kuri yra palankesnè stambiosioms i̇monèms nei gyventojams ar smulkiosioms i̇monèms. Situacija kinta, nes brandžios demokratijos visuomenès nariai jau ne pirmus metus kelia gyvybiškai smulkiosios „žaliosios“ energijos raidai svarbų klausimą - ar situacija, kai „žaliosios“ energetikos versle dominuoja stambaus ir dažnai užsienio kapitalo įmonès, kurios dažniausiai šalyje nepalieka veiklos pelno, nepadidina duotoje teritorijoje verslumo, yra tinkamas? Natūralu, kad visuomenès požiūriu, didžiųjų kompanijų veikla tampa socialiai nepatraukli. Dar nepatraukliau visuomenei, kai tokios stambios šios veiklos kompanijos dar yra ir remiamos (visuomenini interesą atitinkančių paslaugų (toliau - VIAP) fondas). Be to, pastarasis fondas nuolatos didèja. Nors, kita vertus, reikia turèti omenyje, kad tik dalis šio fondo tenka atsinaujinančių išteklių energetikai. Kita dalis skiriama išlaikyti didžiąsias termofikacijos jègaines.

Visai kitaip ,žalioji“ energetika būtų vertinama, jei būtų sudarytos tinkamos sąlygos ją plettoti smulkiajam, vietos (ne tik žemės ūkio) verslui. Teoriškai kiekvienas žmogus galètų tapti energijos (elektros) gamintoju. Pagaminta energija visu pirma būtų paties gamintojo savo reikmèms sunaudojama, o perteklius parduodamas bendruomenei. Tiesioginè nauda būtu veikla užsiimančiam asmeniui, bendruomenès nariams, tiems patiems ūkininkams, diversifikuojantiems savo veiklą ir t. t. Be to, kas itin svarbu visuomenès raidai, būtų tiesioginis kontaktas su verslumo (antreprenerystès) fenomenu. Pirmieji žingsniai šia linkme ne tik pasaulyje, bet ir Lietuvoje jau yra žengti, bet tolesnei plètrai, ypač tokiai, kuri apima net keletą visuomenès raidos sričiu, būtinas gilesnis ne tik mokslinis, bet ir politinès valios nestokojantis požiūris.

\section{Techniniai veiksniai}

Istoriškai susikloste taip, kad tradicinès energetikos technologijos (kogeneracija, atomine energetika ir t. t.) yra ne tik pačios sudètingiausios, bet ir jų diegimo bei veikimo priežiūrai reikia šios srities specialistų-profesionalų. Be to, taikant šias technologijas energetinių produktų gamybai gali būti naudojamas kuras, kuris tiekiamas remiantis technologiškai itin sudetingais procesais. Pastarieji procesai dažnai vykdomi koncentruotai ir kito tokio darinio turèti neapsimoka. Tai viena priežasčių, dèl ko tradicinès energetikos įmonès dažnai vadinamos natūraliomis monopolijomis.

„Žaliosios“ energetikos monopolizavimas tokiu „pasiteisinimų“ neturi tiek daug. „Žaliosios“ energijos prigimtis 
Lentelè. Ekspertinio vertinimo pirmojo etapo apibendrinimas

\begin{tabular}{|c|c|}
\hline Veiksnys / teiginys & Vertinimas \\
\hline \multicolumn{2}{|l|}{ Politiniai } \\
\hline Administraciniai aspektai, skirti iki 350 kW galios elektrinèms & - \\
\hline $\begin{array}{l}\text { Visuomenès ir verslo informavimas apie elektros energetikos smulkiojo } \\
\text { ir vidutinio verslo plètros bei finansavimo galimybes }\end{array}$ & - \\
\hline Patvirtinti ne visi LR AIE istatymo lydintieji teisès aktai & - \\
\hline Teisinis reglamentavimas, skirtas iki 350 kW galios elektrinèms & - \\
\hline Teisinis reglamentavimas, skirtas iki 30 kW galios elektrinėms & + \\
\hline Leidimo gamybai gavimo procedūra, skirta iki 350 kW galios elektrinėms & - \\
\hline Leidimo gamybai gavimo procedūra, skirta iki 30 kW galios elektrinèms & + \\
\hline Administraciniai aspektai, skirti iki 30 kW galios elektrinėms & + \\
\hline \multicolumn{2}{|l|}{ Ekonominiai } \\
\hline „Ž̌alioji“ energetika - tai „saugi“ investicija & + \\
\hline Kainodara, skirta iki 30 kW galios elektrinèms & + \\
\hline Aukcionų procedūra naujoms, didesnèms nei $30 \mathrm{~kW}$, instaliuotos galios elektrinėms & - \\
\hline \multicolumn{2}{|l|}{ Socialiniai } \\
\hline „ZŽalioji“ energetika - tai „,saugi“ investicija & + \\
\hline Darbo vietų kūrimas & + \\
\hline Verslumo fenomeno plètra & + \\
\hline \multicolumn{2}{|l|}{ Techniniai } \\
\hline Prijungimo prie tinklų procedūra, skirta iki 30 kW galios elektrinèms & + \\
\hline Prijungimo prie tinklų procedūra, skirta iki 350 kW galios elektrinèms & - \\
\hline $\begin{array}{l}\text { Elektros tinklu pozicija „žaliosios“ energetikos ir šios srities smulkiuju } \\
\text { gamintojų atžvilgiu }\end{array}$ & - \\
\hline
\end{tabular}

(biomasè, saulè, vejjas, vanduo) dažnai pasižymi maža koncentracija ir didele teritorine sklaida. Galima teigti, kad „Žaliosios“ energijos ištekliai, kad ir nedideliais kiekiais, yra visur mus supančioje aplinkoje.

Pastaruoju metu plinta mini- ir mikro- „žaliosios“ energijos technologijos bei šių technologijų rezultatas - paprastai ịdiegiami, lengvai prižiūrimi energetinių produktų gamybos įrenginiai (saulès kolektoriai, saulès moduliai ir kt.). Formuojasi palankios techninès galimybès net nebūtinai specifines technines žinias turintiems žmonėms gaminti elektros ar šilumos energiją savo ar kitu reikmėms tenkinti. Ypač šios prielaidos sustiprès įdiegus pažangiuosius tinklus, kuriu esmė yra suteikti visokeriopas galimybes vartotojui būti ne tik energijos gavejuu, bet ir gamintoju bei energijos akumuliuotoju.

Remiantis naujai priimtu AIE ịstatymu, itteisintas elektrinių skirstymas i grupes pagal įrengtosios galios dydi, nuo kurio priklauso techniniai tpareigojimai ar palengvinimai. Toks skirstymas mažai naudingas, nes numatomas prijungimo prie energetinių tinklų palengvinimas elektrinėms, kurių įrengtoji galia ne didesnè kaip 350 kW, kol kas praktiškai neveikia. Nèra patvirtintų supaprastintų sąlygų ir nevykdoma tinklų plètra tenkinant norinčių prisijungti poreikius.

Prijungiant prie elektros tinklų mažas ir mikro- elektrines, istatymas numato daug supaprastinimų, kurių esmè, kad „Elektrinès, kurių įrengtoji galia yra ne didesnè kaip 350 kW, gamintojui įvykdžius elektros tinklų opera- toriaus išduotas supaprastintas prijungimo sąlygas, prijungiamos prie elektros tinklų nedelsiant" [8]. Tokia AIE istatymo taikymo nuostata smulkiajam verslui yra tikrai teigiama.

Mažoji kogeneracija, kuri vertintina kaip viena iš palankiausių sričių smulkiojo verslo sklaidai, net ir nepaisant ES direktyvos [9], vis dar išlieka diskriminuojama. Ši diskriminacija susiformuoja dèl neproporcingai didelès administracinès naštos, kurią tenka patirti Lietuvoje naujai diegiant mažą kogeneracinę jègainę, nes sąlygos mažoms jègainėms yra analogiškos, kaip ir didelèms. Darbus dar apsunkina ir praktiškai egzistuojantys technologiniai prijungimo prie tinklų barjerai bei informacijos trūkumas.

Didesnio proveržio ir technologinių prielaidų pagerejjimo galima būtų tikètis tik diegiant pažangiuosius tinklus, kurių pirminè užduotis būtų patenkinti decentralizuotos, smulkiosios gamybos bei akumuliavimo poreikius [10].

\section{Ekspertinio vertinimo rezultatai}

Ekspertai nurode 21 skirtingą veiksni ar teigini, kurie yra svarbūs ir daro ittaką smulkiojo ir vidutinio verslo plètrai elektros energetikos sektoriuje. Iš ekspertų analizès atrinkta 16 skirtingų veiksnių/teiginių, kurie dažniausiai pasikartojo (lentelè). Aštuonis veiksnius (lenteleje pateikiami paryškintai) nurodė ir įvertino vienodai visi ekpertai.

Remiantis ekpertiniu vertinimu, galima daryti išvadą, kad labiausiai smulkiojo verslo plètrą „žaliosios“ energetikos srityje veikia politiniai aspektai - net pusè visų svarbių 
veiksnių yra iš esmès politiniai. Deja, politinè įtaka didžia dalimi yra vertintina neigiamai - net penki iš aštuonių veiksnių ịvardinti kaip darantys neigiamą ịtaką. Tiek socialiniai, tiek ekonominiai veiksniai ar teiginiai, svarbūs smulkiojo verslo plètrai „žaliosios“ energetikos srityje, vertinti teigiamai. Vienintelis ir svarbus neigiamas ekonominis veiksnys - tai aukcionų procedūra naujoms (didesnès nei $30 \mathrm{~kW}$ ) instaliuotosios galios elektrinèms. Techniniai veiksniai daugiau daro neigiamą nei teigiamą ittaką.

Apžvelgus ekpertinio vertinimo rezultatus, galima daryti išvadą, kad tiek esamos situacijos analizè, tiek ekspertinis vertinimas parodé, jog problematiškiausi smulkiojo verslo pletrai „žaliosios“ energetikos srityje yra politiniai sprendimai bei su jais tampriai susiję techniniai veiksniai, kurių ịtaka pasireiškia elektros tinklų visų pirma administracine veikla.

\section{IŠVADOS}

Lyginant situaciją prieš priimant AIE įstatymą ir dabar galima teigti, kad atsirado smulkiosios ,žaliosios“ energetikos sklaidos teigiamų poslinkių. Tačiau senosios prijungimo prie tinklų, administracinès bei informacijos trūkumo kliūtys, kurios labiausiai trukde plèstis AEI, vis dar išlieka, nes kol kas realūs palengvinimai yra taikomi tik mažesnėms kaip $30 \mathrm{~kW}$ ịrengtosios galios elektrinèms.

Teisinès prielaidos visų pirma turètų būti ne tik nuoseklios, t. y. tarpusavyje suderintos Smulkiojo ir vidutinio verslo plètros bei Atsinaujinančių energijos ištekliu isstatymų nuostatos, bet ir visi būtini AEI įstatymą lydintieji dokumentai turètų būti deramai ịvertinti ir patvirtinti.

Teigtina, kad aiškiau apibrěžti irgi yra tik tie teisiniai reikalavimai ir palengvinimai, kurie taikomi mažesnèms kaip $30 \mathrm{~kW}$ ịrengtosios galios elektrinèms. Nors, deja, ir čia nepavyksta išvengti praktinių igyvendinimo problemų.

Vertinant AIE įstatymą, pateikiamas ekonominès skatinimo tvarkos nuostatas reikia atsižvelgti ị tai, kad bet kokių skatinimo priemonių taikymo užduotys būtų orientuotos gerinti technologinę, administracinę bei finansinę aplinkas. Kol kas ypač daug problemų kelia administracinè bei technologine aplinkos. Siekiant konkretaus projekto finansavimo jos yra vertintinos kaip pagrindiniai trukdžiai.

Išanalizavus esamą situaciją, galima teigti, kad didžiausias ekonominis skatinimas numatomas tik ypač mažoms (iki $30 \mathrm{~kW}$ ) elektrinèms, o didesnèms (iki $350 \mathrm{~kW}$ ) jègainèms palengvinimai tèra simboliniai.

Socialiai smulkiosios „žaliosios“ energetikos sklaida būtų labai patraukli sprendžiant visuomeninès naudos, žmonių verslumo skatinimo bei kitas socialines problemas.

Didesnio proveržio ir technologinių prielaidų pagerèjimo galima būtu tikètis diegiant pažangiuosius tinklus, kurių pirminẻ užduotis ir būtų patenkinti decentralizuotos, smulkiosios gamybos bei akumuliavimo poreikius.
Tiek esamos situacijos analizé, tiek ekspertinis vertinimas parodé, jog didžiausia problema smulkiojo verslo plètros „žaliosios“ energetikos srityje yra politiniai sprendimai bei su jais tampriai susiję techniniai veiksniai, kuriu itaka pasireiškia elektros tinklų visų pirma administracine veikla.

Tyrimą finansavo Lietuvos mokslo taryba (sutarties Nr. ATE-01/2011). Tyrimas buvo igyvendintas autoriams bendradarbiaujant su Lietuvos energetikos institutu.

Gauta 20120113

Priimta 20121120

\section{Literatūra}

1. LR Smulkiojo ir vidutinio verslo plètros įstatymas. 1998 m. lapkričio 24 d. Nr. VIII-935, Vilnius, Lietuva. Valstybès žinios. 1998. Nr. 109-2993.

2. Farrell J. Democratizing the Electricity System. A Vision for the 21st Century Grid. The New Rules Project. Minneapolis, USA: Institute for Local Self-Reliance, 2011.

3. Communication from the Commission: Europe 2020. A European Strategy for smart, sustainable and inclusive growth. COM (2010) 2020. Brussels: European Commission, 2010.

4. Pažèraitė A., Krakauskas M. Barriers for implementation of small scale cogeneration in Lithuanian energy market. Proceedings of 6th International Conference on Electrical and Control Technologies ECT-2011, May 5-6, 2011, Kaunas, Lithuania. Kaunas: Technologija, 2011. P. 161-164.

5. Wind Energy Barometer 2010 ir EPIA 2010. Prieiga per internetą: http://www.eurobserv-er.org/pdf/baro201.pdf

6. Libby R., Blashfield R. Performance of a composite as a function of a number of judges. Organizational Behavior and Human Performance. 1978. Vol. 21. No. 2. P. 121-129.

7. Goodnow J. D., Hansz J. E. Environmental determinants of overseas market entry strategies. Journal of International Business Studies. 1972. Vol. 3. No. 1. P. 33-50.

8. LR Atsinaujinančių išteklių energetikos įstatymas. $2011 \mathrm{~m}$. gegužès 12 d. Nr. XI-1375. Vilnius. Prieiga per internetą: http://www3.lrs.lt/pls/inter3/dokpaieska.showdoc_l? p_id=398874

9. Directive 2004/8/EC of the European Parliament and of the Council of 11 February 2004 on the promotion of cogeneration based on a useful heat demand in the internal energy market and amending Directive 92/42/EE. Official Journal of the European Union L 52/50. 2004.

10. ES projektas dèl energetikos infrastruktūros prioritety 2020 m. ir vèliau (2011/2034(INI)). Prieiga per internetą: www.europarl.europa.eu/meetdocs/2009_2014/.../ 859826lt.pdf 
Aušra Pažėraitė, Mindaugas Krakauskas

EVALUATION OF THE POTENTIAL OF SMALL

BUSINESS DEVELOPMENT IN THE “GREEN ENERGY" SECTOR

Summary

The paper deals with the issue of the small business in the renewable energy field. The experience of the renewable energy leaders shows that the exploitation of the potential of renewable energy sources allows to overcome the dependence on the energy import, stimulates economic growth, and enables the creation of new workplaces as well as opening the prospects for the scientific and technological progress. A very healthy solution would be a promotion of "green and small" business. Therefore there is given an analysis of the main political, economic, social, and technological assumptions of "green and small" business development and its evaluation in the paper.

Key words: small business, "green" energy, renewable energy sources
Аушра Пажерайте, Миндаугас Кракаускас

\section{РАЗВИТИЕ МАЛОГО БИЗНЕСА „ЗЕЛЕНОЙ“ ЭНЕРГИИ ОЦЕНКА ВОЗМОЖНОСТЕЙ СЕКТОРА}

Pезюме

В статье рассматривается вопрос о малом бизнесе в области возобновляемых источников энергии. Опыт стран лидеров в области возобновляемой энергии показывает, что использование потенциала возобновляемых источников энергии позволяет преодолеть зависимость от импорта энергии, стимулирует экономический рост и позволяет создавать новые рабочие места, а также перспективы для научного и технологических прогресс. Очень хорошим решением было бы продвижение „зеленого и малого бизнеса“. Статья содержит анализ и оценки основных политических, экономических, социальных и технологических условии для продвижения „зеленого и малого бизнеса“.

Ключевые слова: малый бизнес, „зеленая“ энергия, возобновляемые источники энергии 